www.jmscr.igmpublication.org

Impact Factor 5.84

Index Copernicus Value: 83.27

ISSN (e)-2347-176x ISSN (p) 2455-0450

crossref DOI: _https://dx.doi.org/10.18535/jmscr/v5i3.65

Journal Of Medical Science And Clinical Research

IGM Publication

An Official Publication of IGM Publication

\title{
Prevalence of Hypomagnesemia and Hypocalcemia on Day one and Day Four in Neonates Born in A Tertiary Care Hospital of Western Maharashtra
}

\author{
Authors \\ Dr Pratik Yadav, Dr G G Joag², Dr C D Aundhakar ${ }^{3}$ \\ ${ }^{1}$ Post Graduate Student, Department of Pediatrics \\ ${ }^{2}$ Associate Professor Department of Pediatrics \\ ${ }^{3}$ HOD Department of Pediatrics
}

\begin{abstract}
Introduction: Hypocalcemia is a frequently observed clinical and laboratory abnormality in neonates. Magnesium and calcium metabolism are closely related. The intestinal absorption and the renal excretion of the two ions are interdependent. Association of hypomagnesemia with calcium deficiency is a known disorder in neonates which needs immediate attention. While most cases occur along with calcium deficiency, there are a sizeable number of cases which have primary magnesium deficiency.

Aim and Objectives: To estimate the prevalence of hypomagnesemia and hypocalcemia, study the correlation of hypomagnesemia and hypocalcemia with clinical status of the baby and study the risk factors associated with hypomagnesemia and hypocalcemia in a tertiary care hospital.

Materials and Methodology: This was an analytical observational cross sectional study conducted in Krishna hospital, Karad. 400 babies who were born consecutively in Obstetrics department of Krishna Hospital, and who fulfilled the eligibility criteria were studied. Babies were grouped according to Weight, Maturity, Illness and Treatment. The data was analysed using Student t-test.

Result and Conclusion: Of the 400 neonates studied: On Day 1 of life, Hypocalcemia occurred in 0.5\%, Hypomagnesemia occurred in 1\%. On Day 4 of life, Hypocalcemia occurred in 10.5\%, Hypomagnesemia occurred in 0\%. Clinical symptoms of Hypocalcemia observed were: lethargy (2\%), high pitched cry (1\%), poor feeding $(0.75 \%)$, apnoea $(0.75 \%)$ and jitteriness $(0.5 \%)$. The risk factors for Hypocalcemia observed were: Prematurity, Formula feeding, Infant of Diabetic Mother and Birth asphyxia. Hypomagnesemia was not associated with any clinical symptoms nor risk factor in the study.
\end{abstract}

Keywords: Hypocalcemia, Hypomagnesemia, Neonates.

\section{INTRODUCTION}

Hypocalcemia is a frequently observed clinical and laboratory abnormality in neonates. ${ }^{1}$ Ionized calcium is crucial for many biochemical processes including blood coagulation, neuromuscular excitability, cell membrane integrity, and many of the cellular enzymatic activities. ${ }^{1}$ Neonatal hypocalcemia is defined as a total serum calcium concentration of $<7 \mathrm{mg} / \mathrm{dL}$ or an ionized calcium concentration of $<4 \mathrm{mg} / \mathrm{dL}(1 \mathrm{mmol} / \mathrm{L}){ }^{2}$

Magnesium is a co-factor in more than 300 enzyme systems that regulate diverse biochemical reactions in the body, including protein synthesis, muscle and nerve function, blood glucose control, and blood pressure regulation. ${ }^{3}$ Normal magnesium levels are between $1.7-2.2 \mathrm{mg} / \mathrm{dL}$ with levels 
less than $1.6 \mathrm{mg} / \mathrm{dL} \quad(0.7 \mathrm{mmol} / \mathrm{L})$ defining hypomagnesemia. ${ }^{3}$

Magnesium and calcium metabolism are closely related. The intestinal absorption and the renal excretion of the two ions are interdependent. ${ }^{4}$ In vitro studies have demonstrated that magnesium can modulate parathyroid hormone secretion in a similar way to calcium. ${ }^{4}$ An acute decrease in magnesium concentration stimulates parathyroid hormone secretion, and an acute increase in concentration of magnesium decreases parathyroid hormone seceretion. ${ }^{4}$

Hypomagnesemia is corrected before treatment is begun for hypocalcemia. ${ }^{5,6}$ In response to decreasing serum magnesium levels, the parathyroid gland responds by increasing secretion of parathyroid hormone. However, as intracellular magnesium depletion develops, the ability of the parathyroid gland to secrete parathyroid hormone is impaired and hypocalcemia may ensue. ${ }^{5,6}$

Association of hypomagnesemia with calcium deficiency is a known disorder in neonates which needs immediate attention. While most cases occur along with calcium deficiency, there are a sizeable number of cases which have primary magnesium deficiency. ${ }^{7}$ Symptomatic hypocalcemia unresponsive to adequate doses of IV calcium therapy is usually due to hypomagnesemia. ${ }^{7}$ It may present either as Early Neonatal Hypocalcemia or later as Late Neonatal Hypocalcemia. ${ }^{7}$

Due to lack of adequate published evidence regarding the incidence of hypocalcemia and hypomagnesemia in neonates and their associated clinical features in our region of Maharashtra, as well as my interest, it was decided to conduct a prospective study to assess the incidence of the same in this population at birth by cord blood sample on Day 1 and on Day 4 of life respectively.

\section{MATERIALS AND METHODS}

This was an analytical observational cross sectional study conducted in Krishna Hospital, Karad. 400 babies who were born consecutively in Obstetrics department of Krishna Hospital, and who fulfilled the eligibility criteria were studied.
$2.5 \mathrm{ml}$ of cord blood was collected on day 1 of life in plain bulb. This blood sample was taken to biochemistry laboratory of the institute where the samples were processed as soon as serum separated (Erba full auto EM 360 analyser was used). Follow up blood samples were collected on Day 4 of life of the baby from peripheral vein and the method of processing the samples was similar to that of the cord blood samples on day 1 of life. Babies were grouped according to Weight, Maturity, Illness and Treatment, and Data was analysed using Student t-test.

a) Babies born consecutively in Obstetrics department of Krishna hospital, Karad b)Both sexes c) Preterm d) Term and e) Post term babies were included in the study.

a) Babies of Mothers who were on any Magnesium treatment during pregnancy b)Those babies who were resucitated with sodium bicarbonate/ iv calcium/ iv magnesium c)Babies of mother who were on diuretics/ steroids/ therapeutic magnesium during or before pregnancy d) Babies of Mothers who were having mineral metabolic diseases during or before pregnancy e)Extreme prematurity (gestational age $<28$ completed weeks) and Very low birth weight babies (birth weight $<1500 \mathrm{gms}$ ) f) Babies with history of known hereditary mineral/ bone disease in family g)Babies of Mothers having any breast pathology due to which they cannot breast feed were excluded from the study.

This study was approved by the ethical committee of the hospital and written informed consents were taken from the parents.

\section{RESULTS}

Following were the observations for the 400 neonates studied:

On day 1 of life, 2 cases of hypocalcemia and 4 cases of hypomagnesemia was observed in term neonates $(n=385)$. On day 4 of life, hypocalcemia was observed in 37 cases of term neonates $(\mathrm{n}=$ $385)$ and 5 cases of preterm neonates $(n=15)$. 
Table 1: Mean concentration of Serum Ionic calcium on Day 4 of life in Term and Preterm neonates:

\begin{tabular}{|l|c|}
\hline Maturity: & $\begin{array}{c}\text { Mean Serum Ionic calcium } \\
(\mathrm{mg} / \mathrm{dL})( \pm \text { SD })\end{array}$ \\
\hline Term $(\mathrm{n}=385)$ & $4.291 \pm 0.35$ \\
\hline Preterm $(\mathrm{n}=15)$ & $4.027 \pm 0.44$ \\
\hline $\mathrm{p}$ value & 0.0049 \\
\hline
\end{tabular}

Unpaired t-test was applied. Values expressed as Mean \pm SD. $p<0.05$ considered significant. The above table shows that there was significant statistical difference in the mean values of serum ionic calcium levels measured on day 4 of life in term and preterm neonates.

On day 4 of life, hypocalcemia was observed in 32 cases of exclusively breast fed neonates $(n=366)$ and 10 cases of only formula fed neonates $(n=$ 34).

Table 2: Mean concentration of Serum Ionic Calcium on Day 4 of life in Exclusive breast-fed and only formula-fed neonates:

\begin{tabular}{|l|c|}
\hline Group: & $\begin{array}{c}\text { Mean Serum Ionic Calcium } \\
(\mathrm{mg} / \mathrm{dL})( \pm \mathrm{SD}):\end{array}$ \\
\hline $\begin{array}{l}\text { Exclusive } \\
(\mathrm{n}=366)\end{array}$ & $4.29 \pm 0.34$ \\
\hline Only Formula-Fed $(\mathrm{n}=34)$ & $4.15 \pm 0.49$ \\
\hline $\mathrm{p}$ value & $<0.036$ \\
\hline
\end{tabular}

Unpaired t-test was applied. Values expressed as Mean \pm SD. $p<0.05$ considered significant. The above table shows that there was significant statistical difference in the mean values of serum ionic calcium levels measured on day 4 of life in exclusive breast-fed and only formula-fed neonates.

Table 3: Mean concentration of Serum Calcium on Day 1 and Day 4 of life $(n=400)$ :

\begin{tabular}{|l|c|}
\hline Day: & $\begin{array}{c}\text { Mean Serum Calcium } \\
(\mathrm{mg} / \mathrm{dL})( \pm \mathrm{SD}):\end{array}$ \\
\hline Mean Day 1 level & $10.49 \pm 0.82$ \\
\hline Mean Day 4 level & $8.82 \pm 0.91$ \\
\hline p value & $<0.0001$ \\
\hline
\end{tabular}

Unpaired t-test was applied. Values expressed as Mean \pm SD. $p<0.05$ considered significant. The above table shows that there was significant statistical difference in the mean values of serum calcium levels measured on day 1 and day 4 of life.
Table 4: Mean concentration of Serum Ionic Calcium on Day 1 and Day 4 of life $(n=400)$ :

\begin{tabular}{|l|c|}
\hline Day: & $\begin{array}{c}\text { Mean Serum Ionic Calcium } \\
(\mathrm{mg} / \mathrm{dL})( \pm \mathrm{SD}):\end{array}$ \\
\hline Mean Day 1 level & $5.04 \pm 0.42$ \\
\hline Mean Day 4 level & $4.28 \pm 0.36$ \\
\hline p value & $<0.0001$ \\
\hline
\end{tabular}

Unpaired t-test was applied. Values expressed as Mean \pm SD. $p<0.05$ considered significant. The above table shows that there was significant statistical difference in the mean values of serum ionic calcium levels measured on day 1 and day 4 of life.

Table 5: Mean concentration of Serum Magnesium on Day 1 and Day 4 of life $(n=400)$ :

\begin{tabular}{|l|c|}
\hline Day: & $\begin{array}{c}\text { Mean Serum Magnesium } \\
(\mathrm{mg} / \mathrm{dL})( \pm \mathrm{SD}):\end{array}$ \\
\hline Mean Day 1 level & $2.39 \pm 0.32$ \\
\hline Mean Day 4 level & $2.41 \pm 0.30$ \\
\hline p value & 0.6 \\
\hline
\end{tabular}

Unpaired t-test was applied. Values expressed as Mean \pm SD. $p<0.05$ considered significant. The above table shows that there is no significant statistical difference in the mean values of serum magnesium levels measured on day 1 and day 4 of life.

Table 6: Observed cases of Hypocalcemia and Hypomagnesemia among the 400 neonates studied on day 1 and day 4 of life:

\begin{tabular}{|l|c|c|}
\hline Day: & Derangement: & $\begin{array}{c}\text { No. of Neonates } \\
(\%):\end{array}$ \\
\hline Day 1 & Hypocalcemia & $2(0.5 \%)$ \\
\hline Day 1 & Hypomagnesemia & $4(1 \%)$ \\
\hline Day 1 & $\begin{array}{c}\text { Hypocalcemia with } \\
\text { Hypomagnesemia }\end{array}$ & 0 \\
\hline Day 4 & Hypocalcemia & $42(10.5 \%)$ \\
\hline Day 4 & Hypomagnesemia & 0 \\
\hline Day 4 & $\begin{array}{c}\text { Hypocalcemia with } \\
\text { Hypomagnesemia }\end{array}$ \\
\hline
\end{tabular}

Table 7: Clinical manifestations associated with Hypocalcemia on day 4 of life $(n=20)$ :

\begin{tabular}{|l|c|}
\hline Clinical Manifestations: & No. of Neonates (\%): \\
\hline Lethargy & $8(2 \%)$ \\
\hline High-pitched cry & $4(1 \%)$ \\
\hline Poor feeding & $3(0.75 \%)$ \\
\hline Apnoea & $3(0.75 \%)$ \\
\hline Jitteriness & $2(0.5 \%)$ \\
\hline Total: & $\mathbf{2 0}(\mathbf{5 \%})$ \\
\hline
\end{tabular}


Table 8: Out of 400 neonates studied, 41 neonates were transferred to NICU due to various causes on Day 1 of life $(n=41)$ :

\begin{tabular}{|l|c|}
\hline Indications: & No. of Neonates (\%): \\
\hline Only Hypocalcemia & $2(0.5 \%)$ \\
\hline Only Hypomagnesemia & $4(1 \%)$ \\
\hline Pre-Term care & $15(3.75 \%)$ \\
\hline Infant of Diabetic Mother & $6(1.5 \%)$ \\
\hline Birth Asphyxia & $6(1.5 \%)$ \\
\hline Meconium Stained Liquor & $5(1.25 \%)$ \\
\hline Maternal Abruptio Placenta & $3(0.75 \%)$ \\
\hline Total: & $\mathbf{4 1 ( 1 0 . 2 5 \% )}$ \\
\hline
\end{tabular}

Table 9 Composition of nutrients in Human milk ${ }^{8}$ v/s Formula milk (Lactodex® 1 starter formula) per $100 \mathrm{ml}$ given to neonates in the study:

\begin{tabular}{|l|c|c|}
\hline Nutrients: & Human milk: & Formula milk: \\
\hline Calcium (mg) & 33 & 75 \\
\hline Phosphorus (mg) & 15 & 52.5 \\
\hline Calcium/ Phosphorus ratio & $>2(2.2)$ & $<2(1.42)$ \\
\hline Magnesium (mg) & 4 & 6 \\
\hline Vitamin D (IU) & $0.4-10$ & 45 \\
\hline Carbohydrate (gms) & 7.0 & 8.50 \\
\hline Protein (gms) & 1.1 & 1.95 \\
\hline Fat (gms) & 3.8 & 3.6 \\
\hline
\end{tabular}

\section{DISCUSSION}

Cockburn $\mathrm{F}$ et al $(1973)^{9}$ studied 75 newborn infants suffering from convulsions. In their study, isolated hypocalcemia was present in $19 \%$ of cases and isolated hypomagnesemia in $3 \%$ of the cases. However, in our study no neonate had seizures, hence the occurrence of hypocalcemia and hypomagnesemia cannot be related exactly with the findings of Cockburn $\mathrm{F}$ et al.

In our study the 42 neonates who were detected to have Hypocalcemia on day 4 of life, 20 (5\%) neonates had clinical manifestations suggestive of hypocalcemia which comprised of lethargy in 8 (2\%), high-pitched cry in $4(1 \%)$, poor feeding in $3(0.75 \%)$, apnoea in $3(0.75 \%)$ and jitteriness in 2 $(0.5 \%)$ neonates (table 7). Jain B K et al $(2000)^{10}$ conducted a study 'Serum ionised calcium in Birth asphyxia'. In their study: jitteriness was present in $58.3 \%$ babies, lethargy in $16.7 \%$ babies, poor feeding in $8.3 \%$ babies, irritability in $8.3 \%$ babies and seizures in $8.3 \%$ babies.

In our study we found, of the total 366 neonates who were exclusively breast fed, 32 (8.74\%) developed hypocalcemia on day 4 of life whereas the remaining 34 who were fed with formula feeds, 10 (29.4\%) developed hypocalcemia on day 4 of life. The calcium - phosphorus ratio is more than 2 in human milk which ensures calcium absorption. ${ }^{8}$ The formula feed given to neonates in the study had calcium- phosphorus ration of less than 2 which could have resulted in decreased absorption of calcium (table 9). Chow WI et al $(2015)^{11}$ conducted a study to describe the clinical characteristics of full term neonates with hypocalcemia and to suggest factors associated with neonatal hypocalcemia. The results of their study indicated that formula milk feeding, Parathyroid hormone insufficiency and low serum vitamin $\mathrm{D}$ concentration are associated with the development of neonatal hypocalcemic tetany.

Hypocalcemia is one of the major problems encountered in preterm neonates. ${ }^{12}$ In our study, the mean concentration of serum ionic calcium on day 1 of life in term and preterm neonates was compared with day 4 serum ionic calcium levels which showed a significant statistical difference (table 1). Which suggested that preterm neonates are more susceptible to develop hypocalcemia. This may be explained by the fact that most of the calcium transfer from mother to fetus occurs in the end stages of the third trimester. The fetus accumulates $250-350 \mathrm{mg} /$ day calcium during the third trimester. ${ }^{13}$ As preterm neonates are delivered before that, they have significantly low levels of calcium stores as compared to term neonates. ${ }^{13}$ Taksande AM et al $(2005)^{14}$ studied 110 neonates with neonatal seizures who developed seizures before 28 days of life. In their study: among the term babies, hypocalcemia was found in $10(12.9 \%)$ neonates and hypomagnesemia in $1(1.2 \%)$ neonate. Among the preterm babies, hypocalcemia was seen in $3(9.09 \%)$ and hypomagnesemia in $2(6.06 \%)$ neonates. In our study, we found $0.5 \%$ occurrence of hypocalcemia on day 1 of life and $9.61 \%$ on day 4 of life in term neonates. In preterm neonates, the occurrence of hypocalcemia on day 4 of life was $33.33 \%$.

Healthy term infants undergo a physiological nadir in the serum calcium levels by 24 to 48 hours of age. $^{15}$ In our study, the mean 
concentration of serum calcium and serum ionic calcium on day 1 and day 4 of life for all the 400 neonates who were studied was compared. The results showed decrease in the calcium levels on day 4 of life in comparison with levels of calcium on day 1 of life. Jain B K et al (2000) ${ }^{10}$ conducted a study 'Serum ionised calcium in Birth asphyxia'. In their study: they found out there was significant decrease $(p<0.01)$ in total calcium levels in asphyxiated infants at 48 hours of life $(7.9 \pm 1.7 \mathrm{mg} / \mathrm{dL})$ as compared to the control values at birth $(9.5 \pm 0.9 \mathrm{mg} / \mathrm{dL})$. Asphyxiated neonates showed significantly low $(\mathrm{p}<0.01)$ serum ionized calcium levels at birth $(3.8 \pm 1.5 \mathrm{mg} / \mathrm{dL})$ as well as at 48 hours of life.

Maternal Diabetes was found in 6 cases of our study population. Maternal Diabetes is one of the risk factor for neonatal hypocalcemia. ${ }^{16}$ Hypocalcemia in infants of diabetic mothers may be caused by a delay in the usual postnatal rise of parathyroid hormone or Vitamin D antagonism at the intestinal level from elevated cortisol and hyperphosphatemia that is due to tissue catabolism. ${ }^{17}$ In our study, we found $2(33.33 \%)$ neonates of diabetic mothers who suffered from hypocalcemia on Day 4 of life.

\section{CONCLUSION}

Among the 400 neonates studied, on Day 1 of life: Hypocalcemia occurred in $0.5 \%$ and Hypomagnesemia occurred in $1 \%$. On Day 4 of life: Hypocalcemia occurred in $10.5 \%$ and Hypomagnesemia occurred in $0 \%$. No cases of Hypocalcemia with Hypomagnesemia occurred together at the same time either on Day 1 of life or on Day 4 of life. Clinical symptoms of Hypocalcemia were observed in 20 neonates. The clinical symptoms observed in these 20 cases were: lethargy (2\%), high pitched cry $(1 \%)$, poor feeding $(0.75 \%)$, apnoea $(0.75 \%)$ and jitteriness $(0.5 \%)$. The risk factors for Hypocalcemia observed in the study were: Prematurity, Formula feeding, Infant of Diabetic Mother and Birth asphyxia. Hypomagnesemia was not associated with any risk factor.

\section{REFERENCES}

1. Jain A, Agarwal R, Sankar MJ, Deorari A, Paul VK. Hypocalcemia in the newborn. Indian J Pediatr. 2010 Oct;77(10):1123-8.

2. Steven A. Abrams. Abnormalities of Serum Calcium and Magnesium. Manual of neonatal care. $7^{\text {th }}$ edition, p 297.

3. Viering, Daan H. H. M.; Baaij, Jeroen H. F. de; Walsh, Stephen B.; Kleta, Robert; Bockenhauer, Detlef (2016-0527). Genetic causes of hypomagnesemia, a clinical overview. Pediatric Nephrology: 1-13.

4. Paunier L. Effect of magnesium on phosphorus and calcium metabolism. Pubmed.gov, article 1331782

5. Matsumoto T. Magnesium deficiency and parathyroid function. Intern Med 1995;34:603-4 (Editorial; Comment).

6. Stephanie C. Hsu, Michael A. Levine. Perinatal calcium metabolism: physiology and pathophysiology. Seminars in neonatology (2004) 9, 23-26. Elsevierreview article

7. Heaton FW, Fourman P. Magnesium deficiency and hypocalcaemia in intestinal malabsorption. Lancet 1965; 2:50.

8. K E Elizabeth. Nutrition and Child Development. $5^{\text {th }}$ edition (2015). Section 1: Infant and young child feeding. Table $1.2 \mathrm{~b}$, page 23 .

9. F.Cockburn, J.K.Brown, N.R.Belton and J.O.Forfar (1973) - Neonatal convulsions associated with primary disturbance of calcium, phosphorus, and magnesium metabolism - Archives of disease in childhood, 1973, 48, 99

10. Jain B K, Daljit Singh, Harmesh Singh. Serum ionised calcium in birth asphyxia. Indian journal of Biochemistry, 2000, 15 (1), 36-39.

11. Chow WI et al (2015). Clinical and laboratory characteristics of neonatal Hypocalcemia.

(www.ncbi.nlm.gov/PMC/article/PMC450 4995/) 
12. P Ghai. Essential Pediatrics. $7^{\text {th }}$ edition. Chapter 7: Newborn Infants, Table 7.16, page 129.

13. Andrea $\mathrm{N}$ hacker, Ellen B Fung, Janet $\mathrm{C}$ King. Role of calcium during pregnancy: maternal and fetal needs. Nutrition Reviews Vol 70(7): 397-409

14. Amar.M. Taksande, Krishna Vilhekar, Manish Jain, Mahaveer Lakra (2005) Clinico - Biochemical Profile Of Neonatal Seizures - Pediatric on call; Vol 2 Issue 10:46

15. Ashish Jain. Ramesh Agarwal. Hypocalcemia in the Newborn. Indian Journal Of Pediatrics (2010) 77: 11231128.

16. Steven A Abrams. Abnormalities of serum calcium and magnesium. ( Manual of neonatal care: John P Cloherty, $7^{\text {th }}$ edition, p. 297,298

17. Aviva Lee-Parritz and John P. Cloherty. Diabetes Mellitus. Manual of Neonatal care. $7^{\text {th }}$ edition (2014). Page 17,20. 